\title{
A Brief Review on the Principles of Human Cadaver Preservation and Monitoring of Microbial Degradation
}

\author{
Mohammed H. Karrar Alsharif $1{ }^{2 *}$, Muhammad Musthafa3 ${ }^{3}$, Abubaker Y. Elamin ${ }^{2,4}$, \\ Elmutasim O. Ibnouf ${ }^{5,6}$, Khalid M. Taha ${ }^{7}$, Mamoun A. Alfaki ${ }^{1}$, Younis S. Nour ${ }^{5}$, \\ Khalid Hadi M. Aldosari ${ }^{8}$
}

${ }^{1}$ Anatomy Department, Faculty of Medicine, Prince Sattam Bin Abdulaziz University, Al-Kharj, KSA

${ }^{2}$ Histology and Embryology Department, College of Medicine, Ondokuz Maiz University, Samsun, Turkey

${ }^{3}$ Department of Microbiology and Immunology, Faculty of Medicine, Prince Sattam Bin Abdulaziz University, Al-Kharj, KSA

${ }^{4}$ Emergency Medical Specialtist Department, Al-Ghad International Colleges for Applied Medical Sciences, Al Madinah Al Munawarah, KSA

${ }^{5}$ Department of Pharmaceutical Microbiology, College of Pharmacy, Prince Sattam Bin Abdulaziz University, Al-Kharj, KSA ${ }^{6}$ Department of Medical Microbiology, Faculty of Medical Laboratory Sciences, Omdurman Islamic University, Omdurman, Sudan ${ }^{7}$ Anatomy Department, Faculty of Medicine, University of Science and Technology, Khartoum, Sudan

${ }^{8}$ Prince Sattam Bin Abdulaziz University, Al-kharj, KSA

Email: *dr.anatomy83@yahoo.com

How to cite this paper: Alsharif, M.H.K., Musthafa, M., Elamin, A.Y., Ibnouf, E.O., Taha, K.M., Alfaki, M.A., Nour, Y.S. and Aldosari, K.H.M. (2017) A Brief Review on the Principles of Human Cadaver Preservation and Monitoring of Microbial Degradation. Forensic Medicine and Anatomy Research, 5, 19-31.

https://doi.org/10.4236/fmar.2017.53003

Received: April 27, 2017

Accepted: July 28, 2017

Published: July 31, 2017

Copyright () 2017 by authors and Scientific Research Publishing Inc. This work is licensed under the Creative Commons Attribution International License (CC BY 4.0).

http://creativecommons.org/licenses/by/4.0/

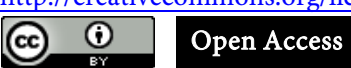

\begin{abstract}
Putrefaction and decay of preserved cadaver and body parts is one of the major issues that the faculties of medicines in various third world countries are facing. In this study we focus on the meaning of body preservation, causes of putrefaction and we highlight our personal experiences at the Faculty of Medicine in Prince Sattam bin Abdulaziz University in KSA, in preserving the body cadavers. We studied different physical and chemical methods of preservation of cadavers and body parts at the faculty and their efficiency in preventing bacteria and fungi that cause putrefaction and decay.
\end{abstract}

\section{Keywords}

Preservation, Mummification, Plastination, Embalming, Putrefaction, Bacterial Isolation

\section{Introduction}

\section{Meaning of preservation}

It's the art and science of human body to treat it with chemical components for preservation by preventing or intercepting microorganisms such as bacteria 
and fungi which are classified as main causes of organic decomposition which lead to putrefaction [1].

Embalming is an ancient art established by old Egyptians [2]. It is worth being mentioned here that, this is used in many purposes such as transportation of dead body from place to another, as religious practice in some countries etc.

In this study we will focus on Embalming for anatomy education. Most of faculties of medicine around the world use the body cadaver for teaching anatomy for medical student and for research, and this type of preservation is called (anatomical preservation) [3].

\section{Types of Body Preservation}

\subsection{Natural Preservation}

This type of preservation occurs by natural factors including freezing and dryness that may occur by dry-heat or dry-cold (Figure 1) and the soil nature [4]. The body or body parts preserved by this can be called the naturally mummified one.

\subsection{Mummification}

It can be divided according to the causative agents which cause preservation of dead body. They are:

A) Natural mummification: This is caused by the Mother Nature which occurs when buried in [5] and climate conditions.

B) Artificial mummification or true mummification: This is the type of preservation that had been done by Ancient Egyptian civilization for religious concepts (Figure 2) [6]. According to Greek historian Herodotus there are three types of artificial mummifications and all of them share the same target of interception of decomposition of the dead body [7].

Different materials had been used in the mummification include materials that desiccate and dehydrate such as natron salt and vegetable materials and those act as anti-bacterial factors such as Mastic, Lichen, Myrrh, Bitumen, Cassia, Onions, Beeswax, Lichen, Coniferous resin, Henna and Gum Arabic [5].

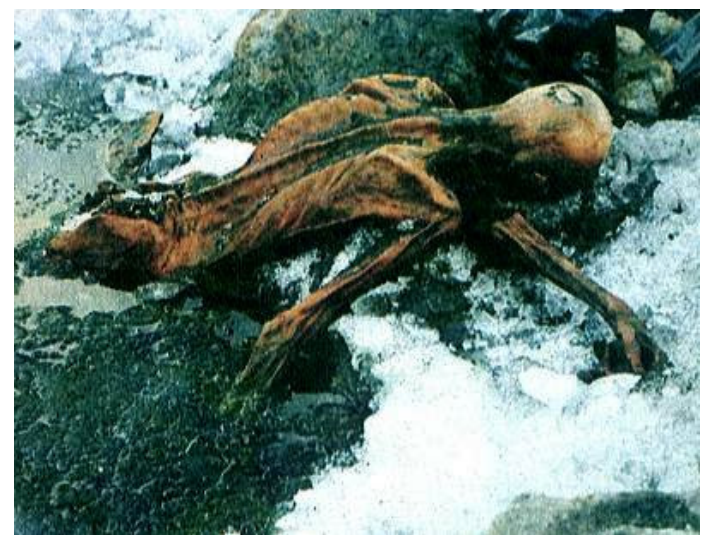

Source: http://familypedia.wikia.com/wiki/\%C3\%96tzi_the Iceman

Figure 1. 5300 year old Iceman found in Alps Mountains. 


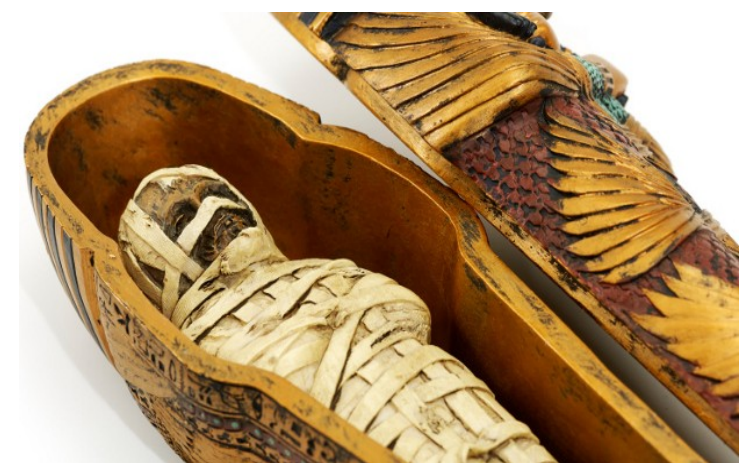

Source:

http://news.softpedia.com/news/Scientists-Mummify-Human-Leg-in-Bizarre-and-Twisted-Experime nt-482441.shtml\#sgal_0

Figure 2. Ancient Egyptian mummy.

\subsection{Plastination}

This is a method or technique used for the long term preservation of body or part of body [8]. This technique was established by German scientist Gunther von Hagens in 1977 [9] in laboratory of Heidelberg University [10]. The main advantage of this way of preservation that the specimens were dry, durable, odorless, handleable and storable manner [11]. In the process of plastination the fluids and lipids in biological tissues substitute by curable polymers commonly epoxy, silicone and polyester. As a result of this procedure the specimen gets harden and a natural look [9] and the decomposition which lead to putrefaction of biological tissues is intercepted.

As previously described many chemicals can be used to replace the fluid and fat this led to provide different techniques of plastination here we will mention some of this techniques.

\section{a) Silicone plastination}

Silicone plastination is one of most common techniques of plastination which can be used for body, organs, part of organ and slices [8] (Figure 3). The Plastination techniques depend on vacuum of original body or tissue fluid and replace it by special curable polymer of the standard silicone S-10 [9]. The fixative chemical mostly use is formaldehyde. This technique was invented by Gunther von Hagens [12].

Silicone plastination consist of four steps after preparation of specimen and are dehydration, defatting, hardening and formaldehyde embalming or fixation (Figure 3, Figure 4).

\section{b) Epoxy plastination}

This techniques of plastination is usually used for tissue examination especially slices of $2-4 \mathrm{~mm}$ [13]. The techniques of preservation are similar to previous one and it substitutes of all water and most of lipid with curable resin [14]. The result of epoxy plastination is durable sectional slices looking like magnetic resonance Image and computed tomography so it suitable for studying anatomy at gross or macroscopic to the microscopic level (Figure 5). 


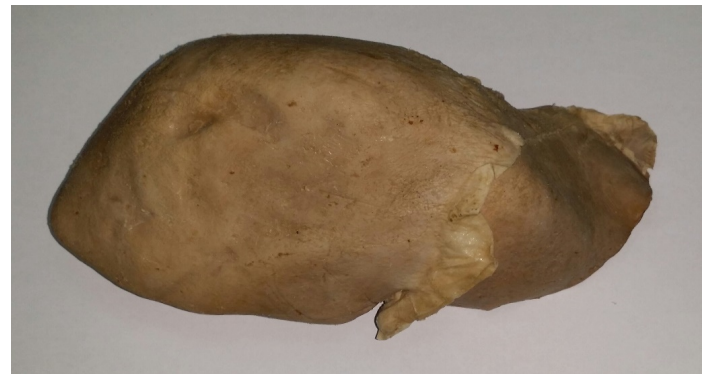

Figure 3. The liver of human cadaver, silicone plastination (Anatomy Lab, Collage of Medicine, Prince Sattam Bin Abdulaziz University).

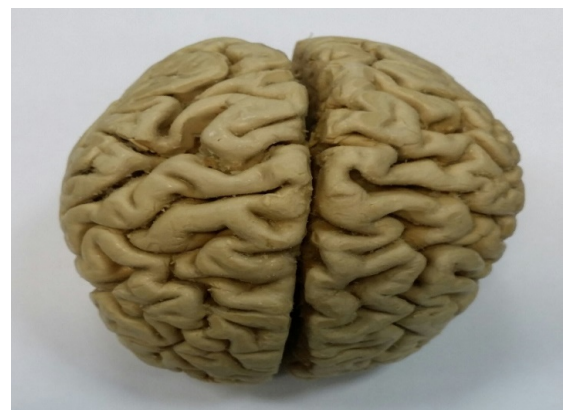

Figure 4. The brain of human cadaver, silicone plastination (Anatomy Lab, Collage of Medicine, Prince Sattam Bin Abdulaziz University).

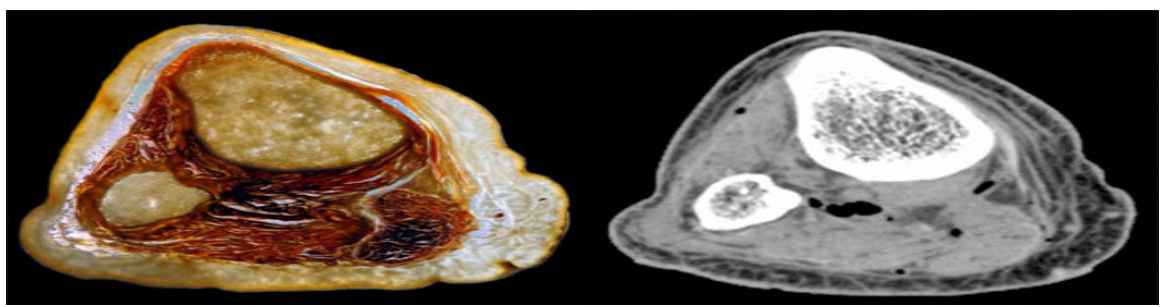

Source: Ottone, N.E., Del Sol M. and Fuentes, R. (2016) Report on a Sheet Plastination Technique Using Commercial Epoxy Resin. International Journal of Morphology, 34, 1039-1043 [15].

Figure 5. Comparison between computed tomography image (right) and epoxy plastinated specimen (left).

According to T. Shahar [13] the chemicals which are used in (generic) epoxy plastination technique and Biodur ${ }^{\mathrm{TM}} \mathrm{E} 12$ sheet epoxy plastination technique are the same which include:

- Fixatives (if necessary)

- Methylene chloride $(\mathrm{MeCl})$ as defatting agents

- Acetone

- Epoxy resin

- Epoxy hardeners to link the epoxy molecules

- Epoxy plasticiser

\section{c) Polyester plastination}

The basic steps in this technique are also the same as described in the earlier procedure. In Polyester plastination the tissue fluids withdrawn and replaced by 


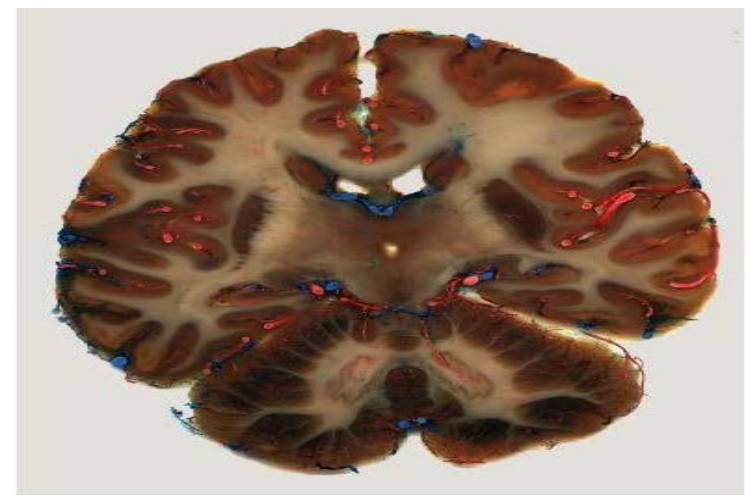

Source: http://www1.zu.edu.eg/plastination/polyester_plastination_1_files/frame.htm

Figure 6. Polyester plastination for semitransparent brain slices.

curable Polyester resin [16] such as P40 as described by von Hagens [17], or P35 resin that has been used by von Hagens or the new comer P45 resin as described by Gao, H [18] [19]. This method is suitable to study the anatomical formation of $4-8 \mathrm{~mm}$ slices of nervous tissue [16] (Figure 6). The basic steps in polyester plastination technique are preparation of specimen, slicing and dehydration. The chemicals used according to Sargon, M.F. [8] include the following:

- fixatives (if necessary)

- acetone

- methylene chloride (if necessary)

- polyester resin.

\subsection{Embalming}

The term of Embalming derived from Latin origin and it define as treatment of body cadavers with special chemicals so as prevent decay or putrefaction, it was an ancient culture and nowadays in modern culture it become substantial science and art due to social and science reason because the preserved body cadaver considered as an ideal teaching tool for anatomy and other branches medical science such as surgery, obstetrics, pathology and radiology [4] [20].

\section{a) Embalming in the ancient cultures}

Many ancient cultures including Egyptian culture practiced embalming as they believed that decayed dead of the body would preclude it from life after death [21]. The basic steps of ancient embalming are:

1) Washing surface and body cavity with palm wine.

2) Removal of brain and internal organs (viscera) and keep it in jars except the heart.

3) Left the internal organ to dry.

4) Cover body with natron salt to dry.

5) After 40 days the body is wash with wine and spices.

6) Return back the organs inside the body.

7) Wrapped the body with linen.

8) Place the body inside coffin. 


\section{b) Modern embalming}

As the relevance of body cadavers in anatomical studies cannot be ruled out, the embalming for preservation became more important. The process of embalming consists of four steps can be summarized as the following:

- Arterial embalming: it is the injection of embalming fluid through the blood vessels usually the common carotid artery. This is to replace the body fluid by embalming solution.

- Cavity embalming: this refers to substitute gas and fluid in the organ and inner side of the body with embalming fluid using a trocar.

- Hypodermic embalming: this is a complementary step to ensure that concentrated embalming fluid reach all parts of the body, especially to those sites of body where the arterial fluids might not reached. This is done by using hypodermic needle and is a case-by-case basis step.

- Surface embalming and washing: this is a (as needed step) remedy or treatment in damaged area in the surface which may occur due to a lot of causes such as skin diseases, cancer, decomposition or other epidermal injury.

Erich Brenner [4] in his great review article mention and compare between different types of modern anatomical embalming techniques in term of long-term storage, advantages and disadvantages and Possibilities of usage in anatomical teaching (Table 1).

\subsection{Embalming Chemicals}

The chemical components of embalming fluid used in modern embalming are variety which includes sterilization and disinfectant agents, preservatives, modifying agents (buffers, anticoagulants, and wetting agents) and dyes [4].

\section{Meaning of Body Putrefaction}

The biodegradation is the breakdown of complex organic materials into simpler chemicals by biochemical process [22]. Actually, the oxidative breakdown of synthetic or natural substances is taken place by microbial activity [23]. Biodegradation of body is the final process of the biological destruction of body and is commonly termed as decomposition or putrefaction [24].

The putrefaction is the destruction of the soft tissues of the body and is it done by two different groups of organisms, i.e., the scavengers and the true decomposers like (bacteria fungi protozoa) [25], and both of them are complimentary to each other in function.

There are two types of scavengers: invertebrates (e.g. flies, ants, mites, dermestids cockroaches etc.) and vertebrates (e.g. fish reptiles, big birds like vultures or mammals like jackals, rodents etc.) [26].

After the death of the human being, foul odour from the decomposing body attracts the houseflies and blow flies [27], and usually these flies arrive the dead body within 2 - 4 hours and put their egg in natural orifice or damaged skin [27].

Then the eggs hatch and the flies come out. Maggots secrets protolytic enzyme 
Table 1. Comparative table of different modern anatomical embalming techniques.

\begin{tabular}{|c|c|c|c|c|}
\hline Technique & Advantage & Disadvantage & Long Term Storage & Teaching (Dissection) \\
\hline $\begin{array}{l}\text { Salafia } \\
\text { (c. 1927-1933) }\end{array}$ & Long term storage & Toxic & $\begin{array}{l}\text { Extremely well when the } \\
\text { coffin sealed }\end{array}$ & Not tested \\
\hline $\begin{array}{l}\text { Kaiserling } \\
\text { (pulvertaft, 1950) }\end{array}$ & Good preservation of colour and form & Only for isolated specimens & Not applicable & Not applicable \\
\hline Jores $(1896,1913)$ & Easy storage & No data available & Satisfactory & Satisfactory \\
\hline Peters (1956) & $\begin{array}{l}\text { Good preservation of intestines doesn't affect the the } \\
\text { dissector's skin, odourless, objects sty smooth and } \\
\text { elastic, colour-preserving }\end{array}$ & No data available & Possible & Satisfactory \\
\hline Erskine (1961) & Soft and flexible less exsiccation & No data available & Satisfactory & Satisfactory \\
\hline Richins et al. (1963) & $\begin{array}{l}\text { Decrease rigidity increased bactercidity and } \\
\text { fungicidity, less Browning }\end{array}$ & No data available & Successful for 2 years & No data available \\
\hline Dayton et al. (1965) & No data available & No data available & No data available & No data available \\
\hline Beck (1966) & No data available & No data available & No data available & No data available \\
\hline Tutsch (1975) & Cheap, odourless & No data available & No data available & Satisfactory \\
\hline $\begin{array}{l}\text { Bradbury \& } \\
\text { Hoshino (1978) }\end{array}$ & $\begin{array}{l}\text { Moderate degree of movability and adequate degree of } \\
\text { hardness for dissection }\end{array}$ & No adequate fixation of brains & No data available & Satisfactory \\
\hline Platzer et al. (1978) & Increase fungicidity, cheap & No data available & $\begin{array}{l}\text { Almost unlimited, when } \\
\text { vacuum packed }\end{array}$ & No data available \\
\hline Logan (1983) & Soft preservation, obviates excessive noxious fumes & No data available & Satisfactory & $\begin{array}{l}\text { Facilitates } \\
\text { micro-dissection }\end{array}$ \\
\hline Frolich et al. (1984) & Soft and flexible & $\begin{array}{l}\text { Slight odour, headache, drowsiness, } \\
\text { mild eye, nose and throat } \\
\text { irritations }\end{array}$ & Up to 10 years & "Suitable" \\
\hline Ikeda et al(1988) & "Well fixed" & No data available & No data available & Satisfactory \\
\hline $\begin{array}{l}\text { O’sullivan\& } \\
\text { Mitchell (1993) }\end{array}$ & $\begin{array}{l}\text { Formaldehyde vapour levels below COSHH limits, } \\
\text { improved tissue preservation, more nature coloration }\end{array}$ & No data available & Proved up to 2.5 years & Satisfactory \\
\hline $\begin{array}{l}\text { Macdonald \& } \\
\text { MacGregor (1997) }\end{array}$ & Less toxic & Grey hue of skin & No data available & $\begin{array}{l}\text { Satisfactory up to } 6 \\
\text { months }\end{array}$ \\
\hline $\begin{array}{l}\text { Coleman \& Kogan } \\
\text { (1998) }\end{array}$ & $\begin{array}{l}\text { Excellent preservative properties, minimal structural } \\
\text { distoration, tissue supple, little desiccation, natural } \\
\text { colours }\end{array}$ & No data available & No data available & Satisfactory \\
\hline Thiel $(1992,2002)$ & High colour preservation, smooth and flexible & $\begin{array}{l}\text { Expensive, disintegration of } \\
\text { muscular tissue, limited for } \\
\text { dissection }\end{array}$ & No data available & High acceptance \\
\hline Powers (2003) & No data available & No data available & No data available & No data available \\
\hline Mills (2010) & High mould preventiong & No data available & No data Available & No data available \\
\hline $\begin{array}{l}\text { Al-Hayani et al. } \\
\text { (2011) }\end{array}$ & Not structural distortion, not colour changes & $\begin{array}{l}\text { Hardening outside the tank, }>2 \\
\text { days for re-softening }\end{array}$ & When waxed, possible & No data available \\
\hline $\begin{array}{l}\text { Anichkov et al. } \\
\text { (2011) }\end{array}$ & Natueal appearance, odourless & No data available & Up to 1.5 years & No data available \\
\hline $\begin{array}{l}\text { Janczyk et al. } \\
\text { (2011a) }\end{array}$ & Neutral smell & $\begin{array}{l}\text { Yellowish coloration, corrosion, } \\
\text { disintegration of abdominal organs }\end{array}$ & Up to 1year & Limited usability \\
\hline $\begin{array}{l}\text { Hammer et al. } \\
\text { (2012) }\end{array}$ & Flexible tissues, aesthetic appearance, less toxic & Expensive & Up to 3 years & No data available \\
\hline Shi et al. (2012) & Less toxic, good preservative properties, low volatility & & Up to 2 years & No data available \\
\hline $\begin{array}{l}\text { Goyri-O'Neill } \\
\text { et al. }(2013)\end{array}$ & Good coloration and flexibility & No data available & $\begin{array}{l}\text { No data available (good for } \\
\text { short term preservation } \leq 6 \\
\text { months) }\end{array}$ & No data available \\
\hline
\end{tabular}


softening the skin and make the way easy into interior of the body [28].

The bacteria are the principal agents which ultimately bring about the final reduction of the biological refuse [29].

Systemic study of the cadaveric bacteriology was undertaken by Burn [30] and he found two groups of bacteria on cadavers. The first group includes anaerobic spore-bearing bacilli (e.g. CI. Welhii), coliforms, micrococci, diptheroids and proteus bacteria which are normally present in the respiratory or. Intestinal tracts and they penetrate the mucosa and rapidly invade the tissue shortly after death. The second group of bacteria includes variety pathogenic and non-pathogenic strains [31]. The marked increase in hydrogen ion concentration and the rapid loss of oxygen in the tissue after death favours the growth of anaerobic organisms. The blood is the most natural nutrient medium for microbial growth [30].

The first visible sign of putrefaction is a greenish discoloration of the skin due to the formation of sulfhaemoglobin in settled blood. The process progresses into distension of tissues due to the formation of various gases (hydrogen sulfide, carbon dioxide, methane, ammonia, sulfur dioxide and hydrogen), especially in the bowels [32]. During putrefaction a number of gases are formed in the tissues e.g. hydrogen sulphide, marsh, methane, carbon-dioxide, ammonia and hydrogen phosphide [33] [34].

There are other factors which affect the putrefaction like the weather. Putrefaction is increased in warm rather than in cold [35].

Some studies [36] [37] [38] have shown the presence of microorganism including pathogenic bacteria in cadavers which are preserved using chemicals or other physical methods. So in this study we analyze the cadavers and body parts preserved using embalming and plastination techniques which carried out at department of anatomy in Faculty of Medicine in Salman Bin Abdulaziz University (KSA). The evaluation of preservation depends on two factors one of which is the minimal tissues and body structural distortion and the second is the microbiological properties which is performed by standard sampling procedures as mentioned somewhere else in this article.

- Usually the unused cadavers stored in refrigerator at $\left(0^{\circ} \mathrm{C}-1^{\circ} \mathrm{C}\right)$.

- Regarding the embalmed cadavers stored in stainless steel tanks with $10 \%$ formaldehyde diluted in water, all the cadavers were injected with embalming fluid.

\begin{tabular}{cc}
\hline \multicolumn{2}{c}{ Composition of Embalming Solution } \\
\hline Ingredient & Proportion \\
\hline Formaldehyde & 4 Liters \\
Ethanol & 1 Liter \\
Glycerin & 1 Liter \\
Eosin & $30 \mathrm{ml}$ \\
Liquid Phenol & 1.5 Liters \\
Water & 5 Liters \\
\hline
\end{tabular}


The evaluation of preservation factors in department of anatomy in $\mathrm{Fa}$ culty of Medicine in Salman Bin Abdulaziz University will take place as the following:

\subsection{Evaluation of Physical Characteristics of Body Cadavers after Embalming}

The assessment of physical characteristics according to Benkhadra [39] depends on the softness and flexibility of body cadaver, and actually we get a positive result because the body cadavers maintained its softness and flexibility, that may be explained by the large amount of muscles proteins fragmentation [39]. The second part of the evaluation depends on the biomechanical testing which can be considered as acceptable in our case, taking the fact in consideration that keeping cadaver in formalin will cause a 50\% stenography in energy absorption and raise the rate of bone crispness [40] and also the mechanical integrity will decrease after embalming due to bone demineralization [41].

\subsection{Sampling for Microbes}

\section{a) Sampling from cadaver for possible bacterial and fungal population}

The samples were collected using standard swabbing procedures from different body parts of the 1) cadaver stored in $10 \%$ formalin, 2) cadaver stored in refrigerator at $\left(0^{\circ} \mathrm{C}-1^{\circ} \mathrm{C}\right)$, and 3$)$ plastinated body parts stored at room temperature.

The swabs were taken from oral cavities, nasal cavities, upper limbs, abdomen, genital area and axilla (Figure 7, Figure 8). The swabs were aseptically plated onto Nutrient Agar (NA, CM0003, Oxoid Ltd., Basingstoke, Hampshire, England) plates and Muller Hinton Agar (MHA, CM0337, Oxoid Ltd., Basingstoke, Hampshire, England) plates. The plates were incubated at $37^{\circ} \mathrm{C}$ for 48 hours (Figure 9). Also, the swabs were plated on Sabourad's Dextrose Agar (SDA, CM0041, Oxoid Ltd., Basingstoke, Hampshire, England) plates and incubated at room temperature for up to 7 days.

\section{b) Sampling for airborne bacteria/fungi}

Sampling for possible airborne bacterial and fungal population was done in the respective rooms/labs where the specimens were kept. This is done by standard non-volumetric air sampling method. The nutrient agar and Muller Hinton agar plates were incubated at $370^{\circ} \mathrm{C}$ for 48 hours and the Sabourad's Dextrose
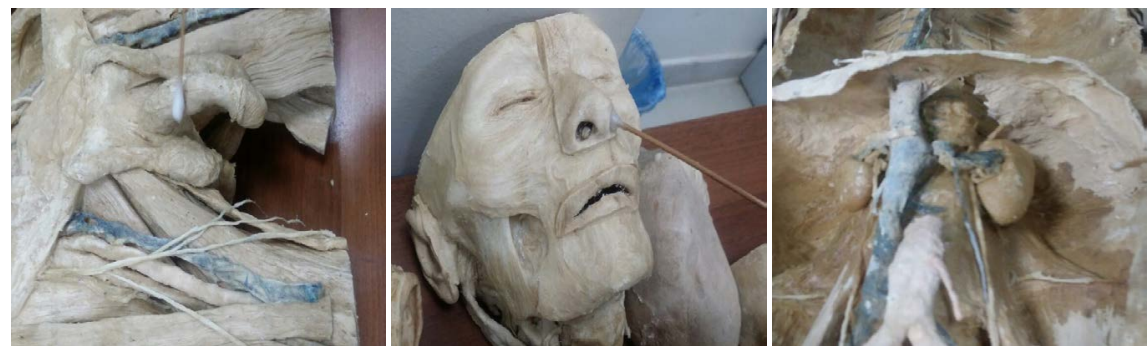

Figure 7. Different sites of sampling on plastinated body parts. 


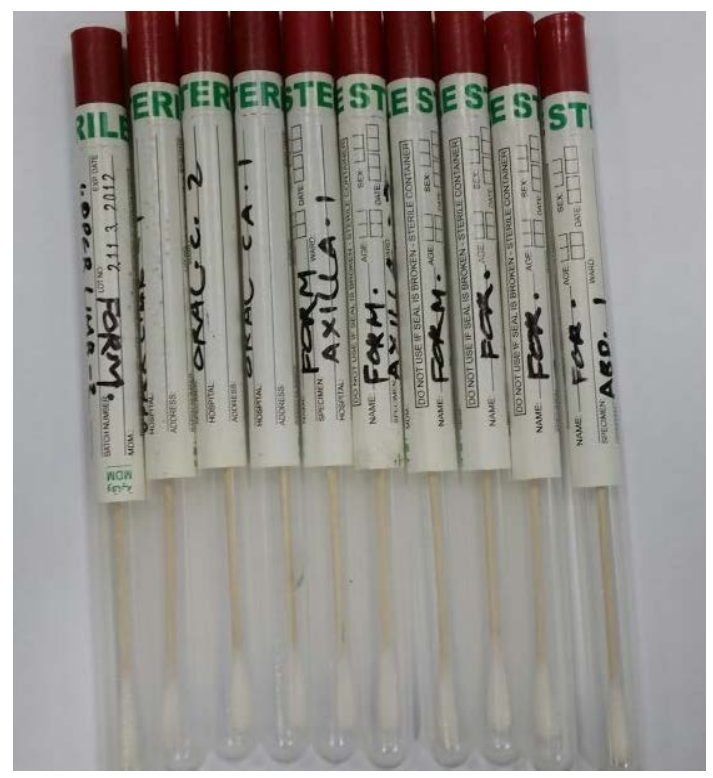

Figure 8. Swabs sampled from different sites.

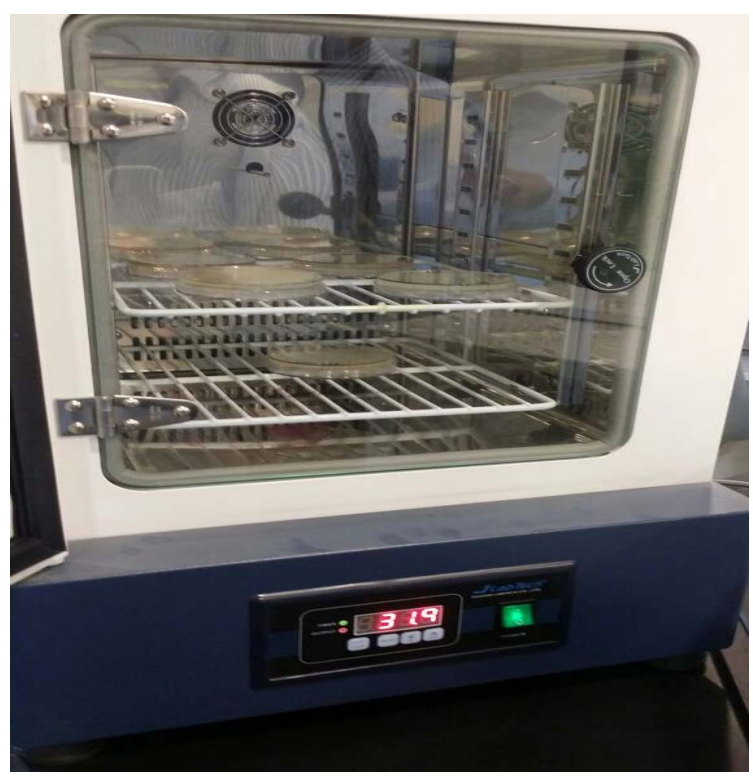

Figure 9. Incubation of plates inoculated with samples.

Agar plates were incubated at room temperature for 7 days.

\section{Identification of the Bacteria/Fungi}

Bacterial isolates were subjected to various morphological and biochemical characterization tests to determine the identity of the bacterial population using standard method [42].

\section{Results and Discussion}

Neither Nutrient Agar plates nor Muller Hinton Agar plates incubated with samples from different sites of plastination, refrigerated and preserved in forma- 


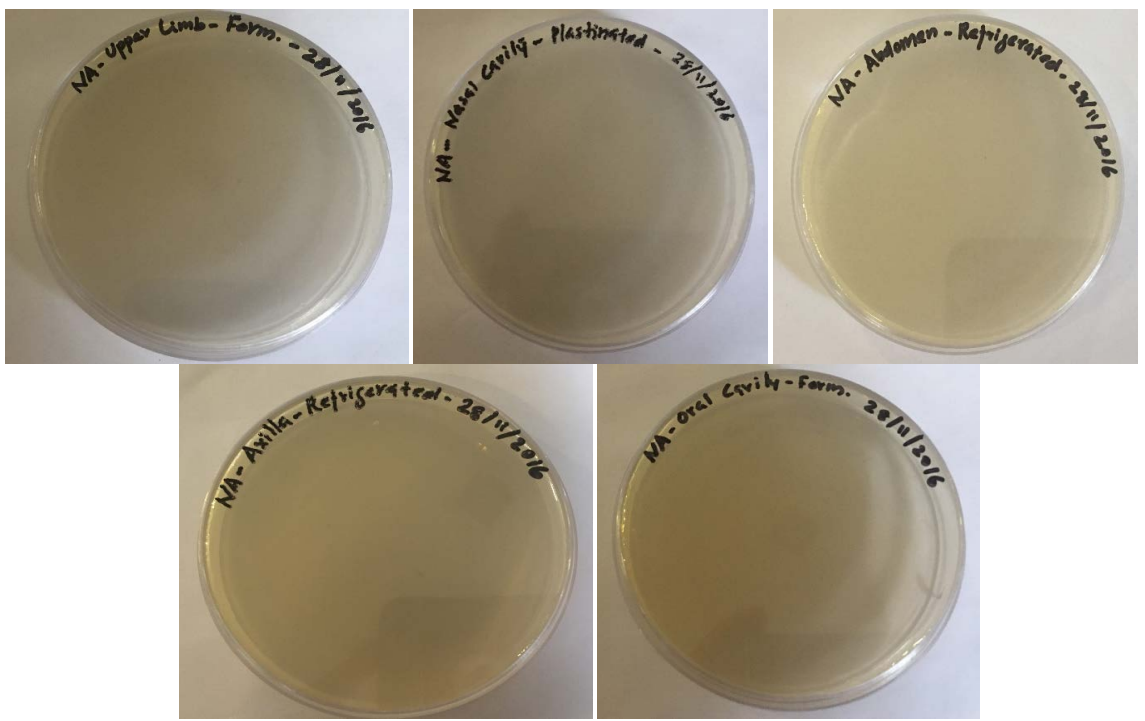

Figure 10. Incubated plates of different samples showing no growth.

lin cadavers/body parts described elsewhere in this article showed any growth of bacteria (Figure 10).

The same was the fate of the Sabourad's Dextrose Agar (SDA) plates which were incubated for possible fungal growth from the cadavers and body parts. This, in turn, proves the higher efficiency of embalming and preservation methods performed at the faculty of medicine, Prince Sattam bin Abdulaziz University. The Nutrient Agar plates which were subjected for airborne bacterial sampling in the Anatomy laboratory where the plastination samples are kept showed the presence of Staphylococcus and Lactobacillus species. At the same time the plates sampled the air of the mortuary shown no growth of bacteria which justifies the intense fumigation effect and the intense odor of formalin which is used as preservative for the cadaver.

\section{References}

[1] Frederick, L.G. and Strub, C.U. (1989) The Principles and Practice of Embalming. 5th Edition, Professional Training Skills Inc. \& Robertine Frederick, Dallas, TX, 1487.

[2] Batra, A.P.S., Khurana, B.S. and Kaur, N. (2010) Embalming and Other Methods of Dead Body Preservation. International Journal of Medical Toxicology \& Legal Medicine, 12, 15-19.

[3] Ikeda, A., Fujimoto, K., Yoshii, I., Matsumoto, S., Nishitani, K. and Ikeda, K. (1993) Arterial Embalming Method of the Cadaver and Its Application to Research. Kaibogaku Zasshi, 68, 410-421.

[4] Brenner, E. (2014) Human Body Preservation-Old and New Techniques. Journal of Anatomy, 224, 316-344. https://doi.org/10.1111/joa.12160

[5] Abdel-Maksouda, G. and El-Aminb, A.-R. (2011) A Review on the Materials Used during the Mummification Processes in Ancient Egypt. Mediterranean Archaeology and Archaeometry, 11, 129-150.

[6] David, A.R. (1990) The History of Mummification. In: David, A.R. and Tapp, E., 
Eds., The Mummy's Tale, St. Martin's Press, London, 37-46.

[7] David, A.R. (2001) Mummification. In: Redford, D.B., Ed., The Oxford Encyclopedia of Ancient Egypt, Vol. 2, Oxford University Press, Cairo, 439-444.

[8] Sargon, M.F. and Tatar, İ. (2014) Plastination: Basic Principles and Methodology. International Journal of Experimental and clinical Anatomy, 8, 13-18. https://doi.org/10.2399/ana.14.040

[9] Pashaei, S. (2010) A Brief Review on the History, Methods and Applications of Plastination. International Journal of Morphology, 28, 1075-1079.

[10] Singh, O., Mishra, B.K., Pandit, S., Maheshwari, T.P. and Hasan, S. (2013) Plastination: A Promising Method for Preserving Biological Specimens: A Review Article. International Journal of Scientific and Research Publications, 3, 1-4.

[11] Dawson, T.P., James, R.S. and Williams, G.T. (1990) How Do We Teach Pathology? Silicone Plastinated Pathology Specimens and Their Teaching Potential. Journal of Pathology, 162, 265-272. https://doi.org/10.1002/path.1711620314

[12] Von Hagens, G., Tiedemann, K. and Kriz, W. (1987) The Current Potential of Plastination. Anatomy and Embryology, 175, 411-421. https://doi.org/10.1007/bf00309677

[13] Shahar, T., Pace, C. and Henry, R.W. (2007) Epoxy Plastination of Biological Tissue: VisDocta EP73 Technque. Journal of the International Society for Plastination, 22, 46-49.

[14] Weber, W. and Henry, R.W. (1993) Sheet Plastination of Body Slices E12 Technique, Filling Method. Journal of the International Society for Plastination, 7, 16-22.

[15] Ottone, N.E., Del Sol, M. and Fuentes, R. (2016) Report on a Sheet Plastination Technique Using Commercial Epoxy Resin. International Journal of Morphology, 34, 1039-1043. https://doi.org/10.4067/S0717-95022016000300036

[16] Latorre, R. and Henry, R.W. (2007) Polyester Plastination of Biological Tissue P40 Technique for Body Slices. Journal of the International Society for Plastination, 22, 69-77.

[17] Von Hagens, G. (1994) Plastination of Brain Slices According to the P40 Procedure. A Step-by-Step Description, $23 \mathrm{p}$.

[18] De Boer-van, R.T., Cornelissin, C.J. and Ten Donkelaar, H.J. (1993) Sheet Plastination of the Human Head. Journal of the International Society for Plastination, 6, 20 24.

[19] Gao, H., Liu, J., Yu, S. and Sui, H. (2006) A New Polyester Technique for Sheet Plastination. Journal of the International Society for Plastination, 21, 7-10.

[20] Natekar, P.E. and Desouza, F.M. (2012) A New Embalming Fluid for Preserving Cadavers. Journal of Krishna Institute of Medical Sciences University, 1.

[21] Johnson, E.C., Johnson, G.R. and Johnson, M. (2012) The Origin and History of Embalming. In: Mayer, R.G., Ed., Embalming-History, Theory, and Practice, McGraw-Hill, New York, 467-509.

[22] Jayovelu, T. (1991) Embalming. B. I. Churchil Livingstone Pvt. Ltd., New Delhi.

[23] Sharma, P.D. (2003) Ecology and Environment. 7th Edition, Rastogi Publication, Meerut.

[24] Clark, M.A., Worrell, M.B. and Pless, J.E. (1997) Postmortem Changes in Soft Tissues. In: Haglund, W.D. and Sorg, M.H., Eds., Forensic Taphonomy. The Postmortem Fate of Human Remains, CRC Press, Boca Raton, 156-164.

[25] Kupchella, C.E. and Hyland, M.C. (1989) Environmental Science. 2nd Edition, Al- 
lyn and Bacon.

[26] Santra, S.C. (2004) Environmental Science. New Central Book Agency (P) Ltd., Calcutta.

[27] Mukherjee, J.B. (1981) Forensic Medicine and Toxicology. Vol. 1, 2nd Edition, Academic Publishers, Calcutta.

[28] Vij, K. (2002) Text Book of Forensic Medicine and Toxicology. 2nd Edition, B. I. Churchill Livingstone Pvt. Ltd., New Delhi.

[29] Forbes, B.A., Sahm, D.F. and Weissfeld, A.S. (1998) Bailey and Scott's Diagnostic Microbiology. Loth, Mosby.

[30] Burn, C.G. (1934) Experimental Studies of Postmortem Bacterial Invasion in Animals. The Journal of Infectious Diseases, 54, 388-394.

https://doi.org/10.1093/infdis/54.3.388

[31] Prieto, J.L., Magana, C. and Ubelaker, D.H. (2004) Interpretation of Postmortem Change in Cadavers in Spain. Journal of Forensic Sciences, 49, 918-923. https://doi.org/10.1520/JFS2003337

[32] Vass, A.A. (2001) Beyond the Grave-Understanding Human Decomposition. Microbiology Today, 28, 190-192.

[33] Gordon, I. and Shapiro, H.A. (1982) Forensic Medicine-A Guide to Principles. 2nd Edition, Churchill Livingstone, Edinburth.

[34] Franklin, C.A. (1988) Modi's Text Book of Medical Jurisprudence and Toxicology. 21st Edition, N M Tripathy Pvt. Ltd., Bombay.

[35] Ministry of Environment and Forest, Government of India (1998) Bio-Medical Waste (Management \& Handling) Rules.

[36] Tabaac, B., Goldberg, G., Alvarez, L., Amin, M., Shupe-Ricksecker, K. and Gomez, F. (2013) Bacteria Detected on Surfaces of Formalin Fixed Anatomy Cadavers. Italian Journal of Anatomy and Embryoloy, 118, 1-5.

[37] Kaufman, M. (2005) Dangerous Dissections: The Hazard from Bodies Supplied to Edinburgh Anatomists, Winter Session, 1848-1849. The Journal of the Royal College of Physicians of Edinburgh, 35, 268-274.

[38] De Craemer, D. (1994) Postmortem Viability of Human Immunodeficiency VirusImplications for the Teaching of Anatomy. The New England Journal of Medicine, 331, 1315. https://doi.org/10.1056/NEJM199411103311918

[39] Benkhadra, M., Bouchot, A., Gerard, J., et al. (2011) Flexibility of Thiel's Embalmed Cadavers: The Explanation Is Probably in the Muscles. Surgical and Radiologic Anatomy, 33, 365-368. https://doi.org/10.1007/s00276-010-0703-8

[40] Goh, J.C.H., Ang, E.J. and Bose, K. (1989) Effect of Preservation Medium on the Mechanical Properties of Cat Bones. Acta Orthopaedica, 60, 465-467. https://doi.org/10.3109/17453678909149321

[41] Fonseca, A., Cherubini, K., Veeck, E., et al. (2008) Effect of 10\% Formalin on Radiographic Optical Density of Bone Specimens. Dentomaxillofacial Radiology, 37, 137. https://doi.org/10.1259/dmfr/18109064

[42] Kranz, R., Weston-Hafer, K. and Richards, E. (2000) Identifying Unknown Bacteria Using Biochemical and Molecular Methods. Washington University in Saint Louis. 
Submit or recommend next manuscript to SCIRP and we will provide best service for you:

Accepting pre-submission inquiries through Email, Facebook, LinkedIn, Twitter, etc. A wide selection of journals (inclusive of 9 subjects, more than 200 journals)

Providing 24-hour high-quality service

User-friendly online submission system

Fair and swift peer-review system

Efficient typesetting and proofreading procedure

Display of the result of downloads and visits, as well as the number of cited articles Maximum dissemination of your research work

Submit your manuscript at: http://papersubmission.scirp.org/

Or contact fmar@scirp.org 